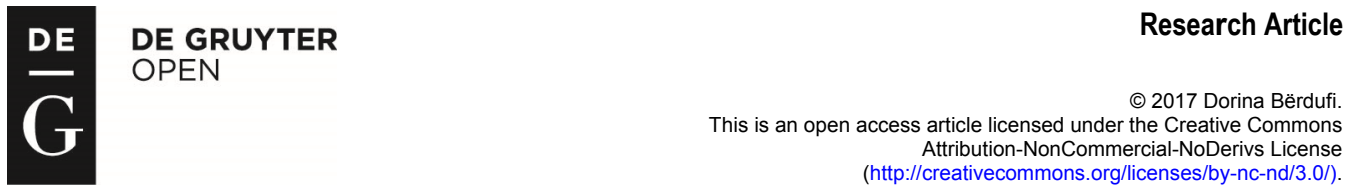

\title{
Possible Capture of Votes Fraud in 2015 Local Election in Albania
}

\section{Dorina Bërdufi}

Aleksandër Moisiu University

\author{
Doi:10.5901/ajis.2017.v6n1p17
}

\begin{abstract}
The paper concentration is on the number of votes each political party acquired in the 2015 local elections. A constant debate and dispute is performed regarding vote counting manipulating, such as vote steeling, uncounted votes, corruption of vote counters, vote buying etc. Thus, statistical calculation on 2015 national results are subject of first digit Benford's Law application. The result shows that all first digit number groups of parties' normal distribution rate of votes do not correlate to the $1 B L$ distribution rate. It is clear that there have been a probable vote fraud/manipulation in this election. Out of three main political parties of Albania, being also parliamentary ones, only one the Socialist Party shows lost vote's number in the group it belongs. Instead the Socialist Movement for Integration and Democratic Party show an increasing one.
\end{abstract}

Keywords: voter turnout, Benford's Law, detection of election fraud/manipulation

\section{Introduction}

This paper follows the first author analyses of 2014 paper "Statistical detection of vote count fraud (2009 Albanian parliamentary election and Benford's Law)". The analysis focuses on the last Albanian electoral results, local election of 2015. This paper mainly relates to the obtained number of votes of each political subject (political party) during the 2015 election. Even though there is a seven - year difference from the 2009 analysis of possible fraud election votes, the situation about this problem is still concerning many of the political arena as also the social field. "The central and local elections are often characterized from a constant debate on manipulation from one party or the other deriving from vote stealing, uncounted votes, disrupting the will of the voters or of the vote counters, purchase of votes etc." (Bërdufi 2014, pg. 755). "Some concerns were expressed about election day procedures, particularly in the vote counting and tabulation" (OSCE/ODIHR, pg. 2). Other problems reported with vote counting are: "unjustified interruption of vote count, prohibition of independent observers in the process of delivery and receiving voting materials, delays and blockages of the counting process. CEC received 23 formal complaints about the count by political party's observers etc." (KZLNDQ, pg.56). As it is a statistical formula, it can be applied only in the tabulated results of vote count, not to the hole process of voting, concentrating only in this marginal aspect of the process which in itself has a great importance. "One should perhaps not expect too much from a test that has only the vote counts themselves to work with." Deckert, Myagkov, and Ordeshook $(2011,248)$ are not deterred by such caveats, arguing that "any inference that the analysis of official returns can begin and end with Benford's Law or that we can dispense with measuring other variables such as the socioeconomic correlates of voting is unwarranted." (Mebane, 2011, pg. 269). In terms of the upcoming 2017 parliamentary election and the main political party's discussion of electronic voting, these results can serve as a support of electronic vote. In this case, we take for granted that there will not be electronic vote manipulation if it is applied. Therefore, we can avoid vote manipulating my humans (commissioners, etc). Nevertheless, it still remains one form of trying to map the election vote possible manipulation. Thus, statistical calculation on 2015 national results is performed to try evidencing if there is any change from the first digit of the Benford's Law results for the parties involved in the local elections. 


\section{Methodology}

"Benford's law, also known as the First - digit or Significant - digit law, is the empirical gem of statistical folklore that in many naturally occurring tables of numerical data, the significant digits are not uniformly distributed as might be expected, but instead follow a particular logarithmic distribution. In its most common formulation, the special case of the first significant (i.e., first non - zero) decimal digit, Benford's law asserts that the leading digit is not equally likely to be any one of the nine possible digits $1,2, \ldots, 9$, but is 1 more than $30 \%$ of the time, and is 9 less than $5 \%$ of the time, with the probabilities decreasing monotonically in between" (Princeton University, pg. 1). "This method is based on tests of the distribution of the digits in vote counts, so all that is needed are the counted vote counts themselves. (Mebane Jr Walter R., July 17, 2006, pg. 1)." (Bërdufi, 2014, pg. 756). The results of each of the 2015 years are grouped into two: one group of parties based on $1 \mathrm{BL}$ vote increase and the other one based on $1 \mathrm{BL}$ vote decrease. This analysis has a deficiency related to evidencing the vote percentage for each party being part of the nine first digit groups. Regarding the detailed result for each of the parties, researchers there should be further statistical analyses. The Benford's first digit formula as follows:

$$
P(d)=\log _{10}+\left(1+\frac{1}{d}\right)
$$

\section{Results and Interpretation}

Election results calculated as per Benford's Law point of view are shown in table 1 and graph 1. The first column of Table 1 shows the first digit of the vote number, the second columns shows the statistical percentage of the normal distribution rate of first digit of the counted electoral votes, the third column shows Benford Rate percentage, while in last column is shown the difference between the two distribution rates 'Sample Rate - Benford Rate'. As it is shown in the table and graph there is no empty field of the first digit Benford's Law; but also, none of the two rates match with each other, meaning that there is a possible electoral vote count fraud (vote count manipulation / problems).

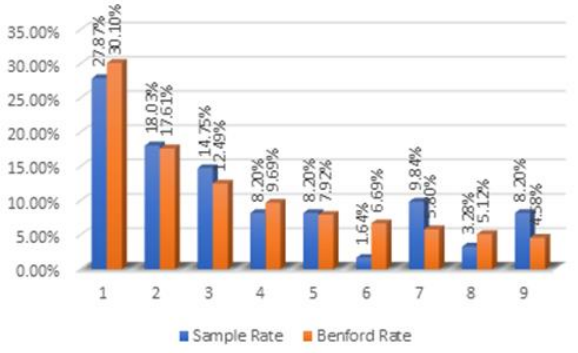

The results of the group of parties based on $1 \mathrm{BL}$ that had a possible increase in their number of votes are the parties which number of votes that start with 2, 3, 5, 7 and 9 . Thus in this group of parties, we can presume that there are parties is this groups that obtained more votes than they statistically should have. Parties that form this five groups are respectively: the parties 1BL that start with 2 are the Right Thinking Liberal Party, Christian Democratic People's Party of Albania, Socialist Movement for Integration, New Democratic Spirit, Christian Democratic People's Party of Albania, Social Democracy Party of Albania, Labor Party of Albania, Party of Albanian Muslim Union, Albanian National Reconciliation Party, Albanian Affairs Party, Social Democratic Party of Albania; the parties 1BL that start with 3 are the Democratic Party, Democratic Movement for Change, Albanian Party of Democratic Reforms, Path of Freedom Party, Europeanisation and Integration Party, Macedonian Alliance for European Integration, Party of Deprived Rights, Alliance for Equality and European Justice, Ethnic Greek Minority for the Future Party; the parties 1BL that start with 5 are the Republican Party, Party for Justice, Integration and Unity, Youth Force Party, New European Democracy Party, Albanian Homeland Party; the parties 1BL that start with 7 are the Conservative Party, Demo Christian Alliance of Albania, Albanian Future Party, People with Disabilities Party, Left Front Party, Candidate proposed from electorate; the parties 1BL that start with 9 are the Albanian Democratic Union, G99, Alliance for Democracy and Solidarity, Communist Party of Albania 8 November. The first digit group of 7 is the one of five ones having the largest difference between sample rate and Benford's rate of $4.04 \%$ followed by the first digit group of 9 at a rate of $3.62 \%$ more than the statistical normal expectation. The following deviance results from the first digit of 3 at a rate of $2.26 \%$. None of the seven - actual 
parliamentary parties are part of the two first groups, while in the third one we find one of three main parties of the Albanian political arena, the Democratic Party. According to the theory, these groups have more possibilities for fraud vote resulting from counting process, vote manipulating, etc. In the other two groups with first digit 2 and 5 there is not a high difference of rates of $0.42 \%$ and $0.28 \%$. In this circumstance, it is accepted that the last two group's normal distribution of 2015 election votes is almost equal to the $1 \mathrm{BL}$. As a consequence, we assert low expectation of vote count fraud for this group of parties. In this two first digit groups are included four of the parliamentary parties, Christian Democratic People's Party of Albania, Social Movement for Integration, Republican Party and Party for Justice, Integration and Unity. Together with the Democratic party, we can say that from seven parliamentary parties five of them belong to the group of parties that probable benefited more votes than they should have as per statistical data.

The results for the group of parties based on 1BL that had a possible decrease in their number of votes are the parties with number of votes that their first digit starts with 1, 4,6 and 8. Thus, we can presume that there are parties is this groups that lost their votes compared to what statistically they should have acquired. Parties that form this four groups are respectively: the parties 1BL that start with 1 Movement for National Development, National Front, Democratic National Front Party, Legality Movement Party, Environmentalist Agrarian Party, Liberal Democratic Union, Time Albanian Party, True Socialist Party '91, Moderate Socialist Party, National Arbnore Alliance, Democratic Alliance Party, Green Party of Albania National Unity Party, Unity for Human Rights Party, Democratic Movement for Progress, Wealth and Values, Ecologic European Alliance, Popular Alliance Party; the parties 1BL that start with 4 Socialist Party of Albania, Party for the Defense of the Rights of the Emigrants, Albanian Movement for Justice, Social Workers Party of Albania, Communist Party of Albania; the parties 1BL that start with 6 New Party of Deprived Rights; the parties 1BL that start with 8 are: Albanian Demo Christian Union, Law and Justice Party. Most of the vote lost according to theory happened to the group of parties that start with the first digit of 6 at the rate of $-5.06 \%$; followed by the group of the first digit of 1 at the value of $-2.23 \%$. In the second one we can find a parliamentary party 'The Human right Union Party'. In the case of the first group, since there is only one party 'New Party of Deprived Rights', we can be more secure to assert that this would have more votes than it obtained in the 2015 elections. The other two groups affirm lower loss of votes, respectively the first digit of 4 at the rate of $-1.49 \%$ and the first digit of 8 at the rate of $-1.84 \%$. In the first group, we find the other main political party of Albania the Socialist Party. Interesting to state is that the two main Albanian parties belong to two different groups, the DP on the side of getting more votes and the SP on the side of getting less votes as per the normal distribution compared to the Benford's one. The third main party in this country the Socialist Movement for Integration, which actually is a co - governmental party, as the DP is part of the group which has more votes than it theoretically should had.

Table 1. 2015 local government electoral results 1BL calculation

\begin{tabular}{|ccccc|}
\hline 1BL & Count & Sample Rate & Benford Rate & SP - BR \\
\hline 1 & 17 & $27.87 \%$ & $30.10 \%$ & $-2.23 \%$ \\
\hline 2 & 11 & $18.03 \%$ & $17.61 \%$ & $0.42 \%$ \\
\hline 3 & 9 & $14.75 \%$ & $12.49 \%$ & $2.26 \%$ \\
\hline 4 & 5 & $8.20 \%$ & $9.69 \%$ & $-1.49 \%$ \\
\hline 5 & 5 & $8.20 \%$ & $7.92 \%$ & $0.28 \%$ \\
\hline 6 & 1 & $1.64 \%$ & $6.69 \%$ & $-5.06 \%$ \\
\hline 7 & 6 & $9.84 \%$ & $5.80 \%$ & $4.04 \%$ \\
\hline 8 & 2 & $3.28 \%$ & $5.12 \%$ & $-1.84 \%$ \\
\hline 9 & 5 & $8.20 \%$ & $4.58 \%$ & $3.62 \%$ \\
\hline
\end{tabular}

\section{Conclusions}

As a conclusion is asserted that all first digit number groups of parties in 2015 Albanian election normal distribution of votes does not correlate to the $1 \mathrm{BL}$ distribution. From the above analyses, it is clear that there have been a probable vote fraud/manipulation in the local election of 2015. Only one of the main political parties of Albania, the Socialist Party, is part of the group positioned on the vote's number losing side, while the Social Movement for Integration and the Democratic Party stand in the other direction group of getting more votes than statistically as per the Benford's theory should have. More logically is that smaller parties vote to have shifted in the course of the main parties. However, to assert this point of view, there are needed further statistical analyses. A possible avoidance of this vote count inconsistencies could be the electronic vote count, with one condition of no machine human manipulation. 


\section{References}

Beber, B. and Scacco, A. (2012) 'What the Numbers Say: A Digit-Based Test for Election Fraud', Political Analysis, 20(2), pp. 211-234. doi: $10.1093 / \mathrm{pan} / \mathrm{mps} 003$.

Benford, F. The law of anomalous numbers, Proc Am PhilosoSoc 78:551-572), 1938

Bërdufi, D. (January 2014). Statistical Detection of Vote Count Fraud (2009 Albanian Parliamentary Election and Benford's Law). Mediterranean Journal of Social Sciences, MCSER Publishing, Rome - Italy, Vol 5 No 2.

KQZ. Zgjedhjet vendore 2015, Numri i votave të fituara sipas subjekteve mbështetës për kandidatët për keshill në shkallë kombëtare, bazuar në rezultatin e votave të fituara në çdo njësi vendore. Miratuar me Vendim të KQZ-së Nr.965, datë 10.08.2015

KZLNDQ, Monitorimi i Zgjedhjeve Lokale, 21 Qershor 2015, në Shqipëri - Raport pëfundimtar.

Mebane, W. R. Jr. (2011). Comment on "Benford's Law and the Detection of Election Fraud", Political Analysis, Oxford University Press on behalf of the Society for Political Methodology. 19:269-272 doi:10.1093/pan/mpr024.

OSCE/ODIHR, (27 April 2015). Republic of Albania, Local Elections, 21 June 2015, OSCE/ODIHR Needs Assessment Mission Report 15-17 April 2015, Warsaw

Princeton University Press, Chapter One, http://press.princeton.edu/chapters/s10526.pdf, (last seen April 2016).

\section{Annex}

2015 election party distribution as per Benford's Law:

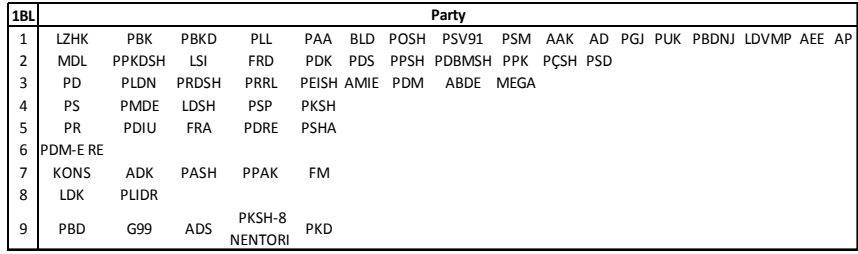

